\title{
Attempts at Applying Cloning to the Conservation of Species in Danger of Extinction
}

\author{
Intentos de Aplicar la Clonación en la Conservación de Especies en Riesgo de Extinción \\ "Mariana Rojas; "Felipe Venegas; "Enrique Montiel; ** Jean Luc Servely; ** Xavier Vignon \& ** Michel Guillomot
}

ROJAS, M.; VENEGAS, F.; MONTIEL, E.; SERVELY, J. L.; VIGNON, X. \& GUILLOMOT, M. Attempts at applying cloning to the conservation of species in danger extinction. Int. J. Morphol., 23(4):329-336, 2005.

SUMMARY: The somatic cloning by transfer of the nuclei of differentiated adult cells to previously enucleated oocytes is a promising technique for the production of embryos of high genetic value. The better mastering of somatic cloning gives us the possibility to produce embryos from endangered species.

The huemul is an Andean native deer, that has been declared an endangered species, it holds a great patrimonial value and it is a Chilean national emblem.

In Chile the huemul has the status of protected animal on thirteen Parks and National Reserves managed by Corporacion Nacional Forestal (CONAF). This protection, however, is considered insufficient due to the few geographical connections between the different protected areas. Furthermore, a great proportion of these areas are not subjected to use or they do not constitute adequate habitats.

Many authors have proposed that the use of biotechnological methods in reproduction and assisted procreation may help conservational programs orientated to the protection of deer species threatened by extinction. All the anterior prompted us to initiate this study concerning the production of cloned huemul embryos.

KEY WORDS: Huemul; Interspecific cloning; Endangered species.

The cloning of a sheep was achieved by Campbell et al. (1996) by transferring the nuclei from cells of the mammal gland in to an enucleated ovocyte of another sheep. Shortly after that, the same authors reported the birth of the first living cloned sheep (Wilmut et al., 1997), named Dolly after the actress Dolly Parton. This cloned sheep evidenced normal reproduction capability, giving birth to six lambs. Later, it presented articulation problems and premature ageing and as a result, it was culled when it reached six years of age (Shields et al., 199 and Lanza et al., 2000a). In this respect, it was reported that the shortening of the telomeres could be related to the ageing problems presented by cloned animals (Giles \& Knight, 2003; Jie \& Xiangzhong, 2003).

In spite of the inefficiency of this process, the technique has been improved and there are reports of 10 animal species that have been cloned successfully, giving birth to normal living offspring. Wells et al. (1998) and Wells (2000) reported the birth of Holstein calves of normal weight without any malformations, after the cloning using somatic cells. As opposed to Dolly, Cumulina, the first cloned mouse obtained from genetic material from the cumulus oophorus (Wakayama et al., 1998, 2000 and Wakayama \& Yanagimachi, 2001) died at the age of two years and seven months, which is considered to be very old for this species.

Bulls and goats have also been cloned by somatic nuclear transference. (Baguisi et al., 1999; Shiga et al., 1999). The first cloning of this kind in pigs was accomplished by Polejaeva et al. (2000) who reported the birth of five healthy piglets. Almost at the same time, Onishi et al. (2000) published the birth of a living clone by direct transference of a nucleus derived from pig fetal fibroblasts into enucleated ovocytes. Chesne et al. (2002) and Challah-Jacques et al. (2003) developed a method for producing rabbit clones. Furthermore, a mule (Woods et al., 2003), a colt (Galli et al., 2003) and even a domestic cat has been cloned which has been alive for 3 years now (Shin et al., 2002).

\footnotetext{
* Laboratorio de Embriología Comparada; Programa de Anatomía y Biología del Desarrollo; Facultad de Medicina, Universidad de Chile, Chile.

** Unité de Biologie du Développement. Institut de Biologie du Development, INRA, Jouy en Josas, France.

Proyecto ECOS-CONICYT C02-B03
} 
Attempts at applying cloning to the conservation of species in danger of extinction. Interspecific cloning. The applications of cloning procedures extend also to the conservation of endangered species and races (Wells et al., 1998; Wells, 2000; Palma 2001). There are many examples in the literature, among others, Bos gaurus, (Lanza et al., 2000a) Bos javanicus and Bucardo (Capra pyrenaica pyrenaica). What is special about these examples is that the authors have had to resort to interspecific cloning. In these cases, the cytoplasm of the ovocyte used in order to form the embryo, derives from common domestic species such as Bos taurus (cow) and Capra hircus (goat), whereas the nucleus are provided for the endangered species. The major problem that arises in this kind of interspecific cloning is the fate of the mitochondria from the receptive ovocyte (DaYuan Chen et al., 2002), due to the fact that the embryo reconstructed in this way may contain mitochondria from both species (Holt et al., 2004).

Progress has also been made in the cloning of the giant panda bear (Ailuropoda melanoleuca) (Saegusa, 1998). According to Da-Yuan et al., the interspecific cloning of this animal is practically impossible because of an insufficient number of ovocytes, as the female Panda produces only one or two ovocytes a year. The only possibility to clone these animals is the technique of interspecific cloning involving the transference of nuclei from cells of the giant panda into enucleated ovocytes from another bear species, the gestation being established in a species different to the nuclei donor species.

A new species of Vietnamese ox, weighting approximately 100 kilos and known as Saola or Vu Quang Ox (Pseudoryx Nghetinhensis) was discovered in 1993 (Dung et al., 1993 and 1994). Unfortunately, only about a hundred animals are alive today (Kemp et al., 1997), in consequence, it is considered an endangered species (Red List of Threatened Species). The functioning of the Saolas embryo genome is currently being characterized in France. These embryos have been obtained after the fusion of a Saolas cell nucleus to the cytoplasm from the ovocyte of a filogenetically close species, such as cattle. Studies are underway in order to establish how nuclear-cytoplasmic interactions occur between these two closely related species at early developmental stages (Service Presse INRA). Regarding this study, six-day embryos have been obtained by the cloning method and are currently kept frozen, waiting to be implanted into a surrogate mother.

In these three cases analyzed, interspecific cloning must be performed. The main problem of this procedure occurs in the first generation and it is due to the mitochondria issue previously described. However, it is worthwhile to point out that if the nucleus comes from the male individual of the species of interest the reconstructed embryo, and even more, the first generation may present mitochondria from both species. This problem can be overcome if the cloned male reproduces naturally with a female of the species of interest, because the paternal mitochondrias are not transmitted to the next generation. This argument cannot be applied to the female because the mitochondrias are inherented through the maternal cytoplasm (Sutovsky et al., 2000; Da-Yuan et al. and Holt et al., 2004).

Natural reproduction should be the preferred method to increase the number of individuals of a determined species. This is not the case, however, when the population of the wild species is in decline. Reproductive technology may represent an important support, forming genetic reserve banks of endangered animals (Holt et al., 1996; Holt \& Pickard, 1999, Watson \& Holt, 2001 and Holt et al., 2002) and the reproduction technology for the conservation of wildlife. Reproduction by cloning could be one of the methods used to increase the number of individuals in a population. It is well known that populations with low numbers of individuals posse a minimal genetic variation, but if some of the individuals fail to reproduce, a loss of genetic variation will occur. According to Holt et al. (2004) a possibility for small populations could be to clone each individual (not impossible if the population size is between 9-18 animals), this allows the offspring to grow, mature and reproduce in a natural way. The probability of loss of genetic variation can be reduced, especially if every parent gives rise to two identical copies of itself. This is an interesting theoretical model for animal conservation.

Native Chilean mammals declared vulnerable or endangered species. There are many endangered mammal species in Chile. Among them there are some native carnivors such as the puma (Puma concolor), the andean mountain cat (Oreailurus jacobita), the guiña (Oncifelis guigna), the argentinian mountain cat (Oncifelis geoffroyi), the colocolo cat (Lynchailurus colocolo), grey or chilla fox (Pseudalopex griseus), Chiloé's fox (Pseudalopex fulvipes), red or culpeo fox (Pseudalopex), and the huillín (Lontra provocax). There are also grain eating species, such as the mountain chinchilla (Chinchilla brevicaudata) and the coast chinchilla (Chinchilla manigera) which are also threatened by extinction.

Among the native ruminants that have been considered as protected species there are three cervidae: the andean huemul or taruca (Hippocamelus antisensis), the pudu (Pudu pudu), a small deer native to Chile and Argentina, that has been considered one of the smallest deer in the world and has been declared a vulnerable species (Glade, 1993) and the southern huemul (Hipocamelus bisulcus). Other 


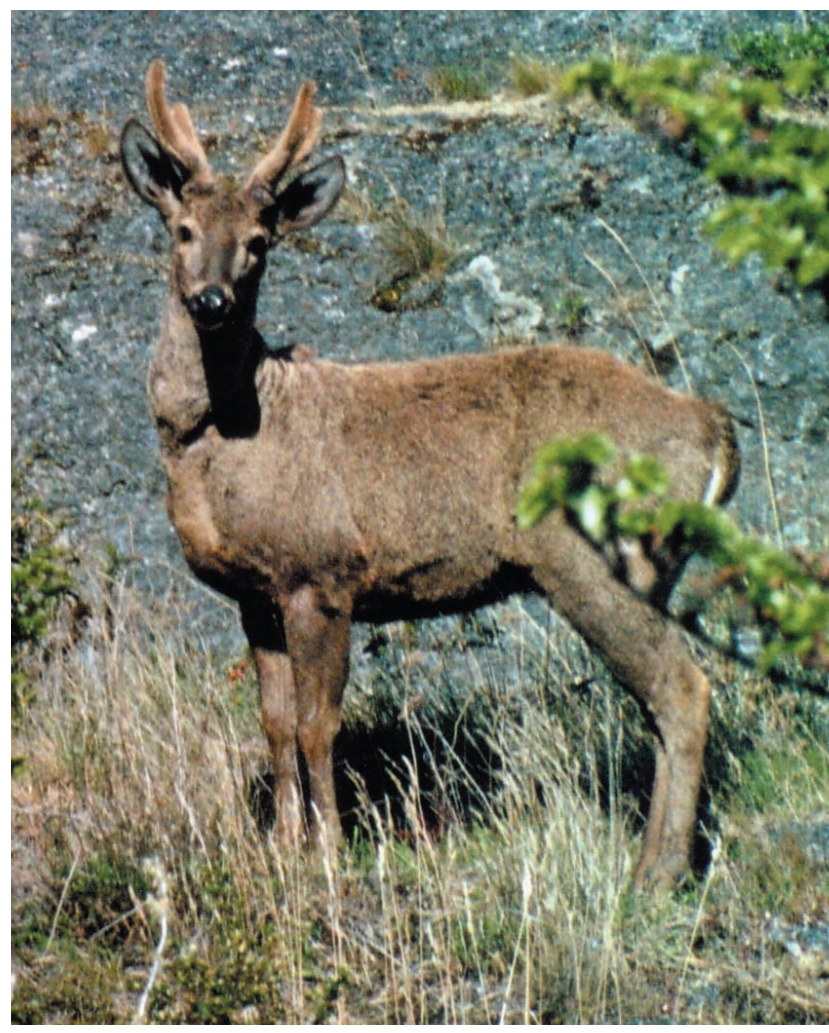

ruminants are the vicuña (Vicugna vicugna) and the guanaco (Lama guanicoe). From now on we will refer to the southern huemul because out of all these endangered species, this is particularly the more emblematic in Chile.

\section{Characteristics of the Southern Huemul (Hipocamelus} bisulcus). The Southern Huemul (Hippocamelus bisulcus) Molina 1782, is a native deer that inhabits the southern Chilean and Argentine Andean Mountains. It belongs to the Mammal Class, Order Artiodactyla, Family Cervidae. Historically, it was distributed between Central Chile (34 $\mathrm{S})$ and the Estrecho de Magallanes $\left(54^{\circ} \mathrm{S}\right)$ but actually. it has been declared an endangered species that risks extinction. Its actual population is estimated in less than 1000 individuals gathered in isolated and fragmented groups (Aldridge, 1988; Saucedo \& Gill a, b, c, 2004). It is included in the Red Book from the World Union for Nature (I.U.C.N.), besides the protection regulation performed for national and international private organisms such as the World Wild Fund (W.W.F.).

In Chile, the huemul is considered a protected animal on thirteen Parks and National Reserves managed by Corporacion Nacional Forestal (CONAF). This protection, however, is considered insufficient due to the few geographical connections presented between the different protected areas. Furthermore, a great proportion of these areas are not subjected to use or they do not constitute adequate
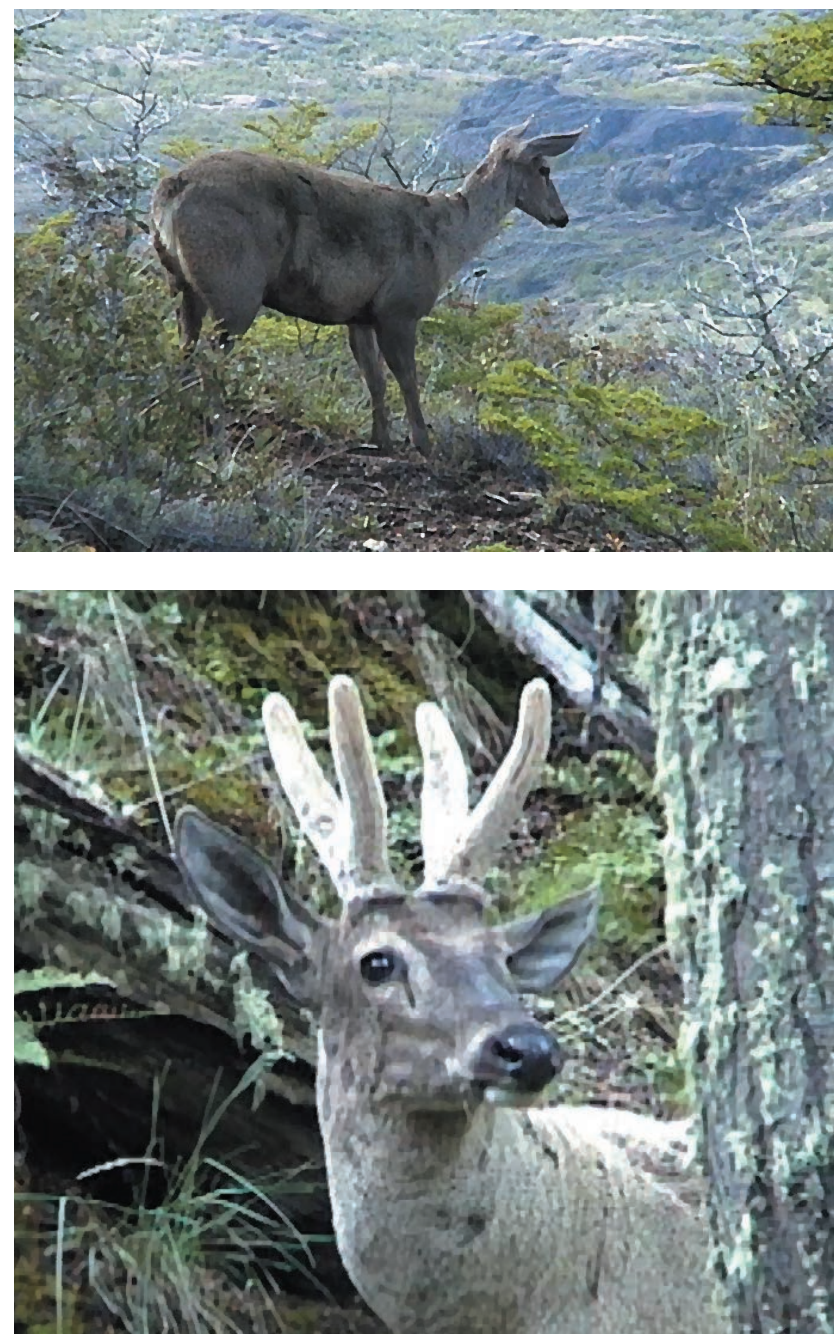

habitats. The major threats for the species are the alteration of its natural habitat due to forest fire, forest cut down and stockbreeding, illness transmitted by domestic cattle (Povilitis, 1998; Diaz \& Smith 2000; Serret, 2001; Saucedo, 2004a,b), illegal hunting, dog predation, and its natural predator the puma (Puma concolor).

A huemul weights between 45 and 65 kilograms (100 - 140 pounds). Adult male specimens can reach 90 to 100 $\mathrm{cm}$ at the withers and have a body size and weight higher than those showed for the females. These have a height of $80 \mathrm{~cm}$ and an average weight of about $65 \mathrm{~kg}$. The huemul can be considered a medium size animal, stockily built, with relatively short legs, characteristics that demonstrate its great adaptation to the steeped and rocky territory that constitute its natural habitat (Acosta-Jamett, 2004).

Its social organization has been studied during spring time, when it has been observed that they constitute small groups of individual from both sexes (Povilitis, 1983b, 1985; Frid, 1991, 1994,1999 y 2001). These groups occupy higher 
places in summer; descending the mountains and staying in forested valleys during winter time. This altitudinal migratory behavior, described a long time ago, shows some differences with reports from Saucedo \& Gill (2004a,b,c) whom, by using radiocollars, were able to follow the movements of the animals thus observing short displacements in a relatively small area of approximately 400 ha. The analysis of the selected habitat revealed a preference for the "lenga" (Nothofagus pumilio). The areas with freshwater sources were preferred. This deer feeds principally from grasses and bush vegetation (Saucedo \& Gill, 2004c).

Reproduction: The huemul is an animal of seasonal reproduction, which implies an alternation between periods of sexual resting and sexual activity determined by the photoperiod (variations between the hours of light and darkness). It is characterized for presenting rutting periods between March to May and the gestational period spans over 7 months, with only one fawn being born. The birth season takes place on spring time, from the beginning of November until the first days of January, a period very favorable for the growing of the fawn. The fawn are born weighing approximately $3,5 \mathrm{~kg}$. (Jara et al., 2003)

There is no precise information on the literature about different reproductive parameters of male huemuls, such as ejaculated seminal volume $(\mathrm{ml})$, sperm cells concentration per $\mathrm{ml}$, morphology of the sperm cells in the ejaculated, testicular volume evolution, progression of the germinal line and interstitial (Leydig) cells during the annual reproductive cycle. There is also no detailed information available about the anatomy of the reproductive tract, cycle length, estrus duration or if delayed implantation exits or not. However, we can extrapolate a few facts from what it is known in other deer species: 1) Each year the males present a resting gonadal phase, recrudescency, activity and gonadal regression, 2) the animal is no fertile during the two first phases. During the active phase, the germinal line is completed and the interstitial cells differentiate, increasing in size and elaborating high concentrations of testosterone, which is related to the sexual drive and the sexual secondary characters, such as a greater development of the antlers (Lincoln \& Short, 1980; Drion et al., 2003 y Locatelli et al., 2005).

Embryonic Development. There are no thorough works in relation with the huemul embryonic development, however, extrapolating from what is known from other cervidae it is inferred that the uterus is bicorneal and that it presents endometrial carunculae. Following the fertilization and segmentation the embryo reach the blastocyst stage and after hatching its stay in spherical form for a few days and locates in the ipsilateral horn. Later, the trophoblast growth is directed towards the contralateral horn. The embryonic disk does not growth too much but the trophoblast elongates forming a filament of about $30 \mathrm{~cm}$ long. Placentation is of the synepitheliochorial and oligocotiledonical type. It is possible to observe six to eight trophoblastic cotyledons forming placentomes with uterine carunculae. Both the trophoblast and the allantois undergo a phase of elongation similar to what occurs in other ruminants (Drion et al.). In the majority of deer there also exists a reproductive strategy called embryonic diapause, Diapause is observed in the roe deer (Capreolus capreolus), only but it is not known if this also occurs in the huemul.

In its first month of life, the fawn is immature; its walking performance is still unstable and keeps hidden and quiet during most of the time, changing places after suckling. The weaning probably takes place after the fourth month of age, because some fawns have been observed still suckling at that age. At the second month of age they frequently feed on vegetation. The growth of juvenile individuals is relatively fast as a yearling male has already reached the size of an adult female.

At present, the scarce evidences of the presence of fawns or juveniles at the region of Nevados de Chillán, may indicate either a decrease in the birthrate or an increase in the natural mortality rate which, in both cases, may leads to the extinction of the population in a short period of time (Povilitis 1983a; 1998; 2002; Plan to the conservation of the southern Huemul). Studies performed between 1980 and 2003 have shown a $80 \%$ decrease in the huemul population at Reserva Nacional Nuble (Acosta-Jamett, 2004). After 1995, a strong decrease in the number of huemul specimens was observed and this was probably related to the great snow storm of 1995 , which may be responsible for the disappearance of many groups both inside and outside the protected area. The same author suggests following more intense activities in order to reestablish the habitat, otherwise the species will became definitely extinct in central Chile.

In agreement with Locatelly \& Mermillod, the use of reproductive biotechnology and methods of assisted procreation may help conservational programs orientated to the protection of deer species threatened by extinction. The implementation of classical techniques of production of embryos based on super ovulation, artificial insemination and embryonic transfer, have resulted extremely difficult for deer species. In addition to these, the characteristics of the huemul do not allow its successful husbandry in captivity. All the anterior prompted us to initiate this study concerning the production of cloned huemul embryos. From an ethical point of view, we must emphasize that our best interest is to 
help the conservational programs by optimizing the process of clone reproduction. The techniques to be used do not posse any danger or suffering to the animals. On the other hand, the genome of the species will be conserved with no introduction of other genes; neither genetics manipulation procedures will be performed. The techniques to be used will not induce any alterations on the ecosystem.

The huemul an animal species seriously threatened by extinction (Povilitis, 1983a; Frid, 1991, 1994, 1999, 2001). It holds a great patrimonial value and it is one of the Chilean national emblems. The anterior constitute enough reason to justify the obtaining of a blastocyst embryo constituted by the inner cell mass from the huemul and the trophoblastic cells (future placenta) from another deer and to follow its subsequent development after the in vivo transference into a surrogate female.

As in the cases of the panda bear (Da-Yuan et al.), and the Saola ox, the lack of huemul females donors of ovocytes, receptive females and the interspecific barriers largely compromise the success of the cloning technique. In fact, embryos obtained by somatic cloning from a determined species, such as the huemul, can not be implanted into the uterus of a receptive female from a different species. In the implantation, only the extra-embryonic trophoblast is involved in the interactions associated with maternal tissues. To deal with this problem it will be necessary to construct a chimeric embryo constituted by trophoblast from the same species of the surrogated female and the inner cell mass from the huemul. This approach may allow the clone to develop successfully, and the trophoblast from a ruminant species (compatible with the receptive female) may allow a better implantation and the subsequent successful development of the clone. It must be kept in mind that the inner cell mass will originate the embryo and embryonic annexed and the trophoblast will produce the placenta.

The development of chimerical embryos will allow the role played by the trophoblast of the surrogate species in the growing of the experimental embryo to be established, and also to analyze some abnormalities in the embryonic development, comparing them with those found in the somatic cloning of some bovine species (Heyman et al. (1995). Therefore, the hypothesis of our lab is that "the development of embryos constituted by embryonic cells from the huemul and trophoblast cells from a different origin, such as the red or dama deer, will allow a better implantation and subsequent development of the embryo in a foster mother from different specie".

Several arguments in favor of the cloning programs of endangered species have been proposed by authors such as Ryder \& Benirschke, 1997; Ryder, 2002; Lanza et al., 2000b; Wells; Ryder et al.; Ryder, Critser et al., 2003 and Rojas et al., 2004). However, once the clone birth as been achieved it is important to consider a care and observation program for the first generation of newborns. Holt et al. (2004) have indicated that the first generation of the cloned descendants must be kept in a proper place for observation and veterinary handling. An inadequate nuclear re-programming and phenotype abnormalities can compromise the success of the total population, however in some species these abnormal phenotypes are not inherited for the next generation. This has been observed in the mouse (Shimozawa et al., 2002) and the pig (Prather et al., 2003). These studies show that cloning may became a potential tool in conservationism, taking into account the restrictions of the effects on the first generation, on the one hand, and the possibility to obtain a second generation of healthy individual, on the other.

ROJAS, M.; VENEGAS, F.; MONTIEL, E.; SERVELY, J. L.; VIGNON, X. \& GUILLOMOT, M. Intentos de aplicar la clonación en la conservación de especies en riesgo de extinción. Int. J. Morphol., 23(4):329-336, 2005.

RESUMEN: El clonaje somático por transferencia del núcleo de células diferenciadas adultas a un ovocito, al que se le ha extraído el núcleo (enucleado), es una técnica prometedora para la producción de embriones de alto valor genético. El mejor dominio del clonaje somático da la posibilidad de producir embriones de especies amenazadas de extinción.

El huemul es un ciervo andino autóctono, declarado como especie en peligro de extinción. tiene un gran valor patrimonial, y es emblema de la nación chilena. En este país, el huemul se encuentra protegido en trece Parques y Reservas Nacionales, manejadas por la Corporación Nacional Forestal (CONAF). Sin embargo, su protección se considera insuficiente debido a la baja conectividad entre las áreas protegidas y además, una gran proporción de estas áreas no son utilizadas o no constituyen un hábitat adecuado.

Para las especies de cérvidos en vías de extinción el uso de biotecnología reproductiva y métodos de procreación asistida, según varios autores, pueden ayudar a los programas de conservación. Las técnicas clásicas de producción de embriones basados en superovulación, inseminación artificial y transferencia embrionaria,en los cérvidos, han resultado muy dificultosa. Esto, sumado a las características del huemul, que no permite su estabulación en cautiverio, nos ha movido a iniciar un estudio tendiente a la producción de embriones clonados de esta especie.

PALABRAS CLAVE: Huemul; Clonación interespecífica; Riesgo de extinción. 


\section{REFERENCIAS BIBLIOGRÁFICAS}

Acosta-Jamett, G. Environmental catastrophe induce a decline in the endangered northernmost Huemul (Hippocamelus bisulcus) deer population in central Chile. Deer specialist group. Newsletter, 19:10-3. 2004.

Acosta-Jamett, G. Proyecto conservación del huemul, Región del Biobio, Chile. Corporación Nacional Forestal, Patrimonio Silvestre. http://www.salvemosalhuemul.cl/conten/ proyectos/principal.htm\#top, 2004.

Aldridge, D. Proyecto conservación del huemul (Hippocamelus bisulcus) en Chile. Medio Ambiente (Chile), 9:109-16. 1988.

Baguisi, A.; Behboodi, E.; Melican, D. T.; Pollock, J. S.; Destrempes, M. M.; Cammuso, C.; Williams, J. L.; Nims, S. D.; Porter, C. A.; Midura, P.; Palacios, M. J.; Ayres, S. L.; Denniston, R. S.; Hayes, M. L.; Ziomek, C. A.; Meade, H. M.; Godke, R. A.; Gavin, W. G.; Overstrom, E. W. \& Echelard ,Y. Production of goats by somatic cell nuclear transfer. Nat. Biotechnol., 17:456-61, 1999.

Campbell, K. H.; McWhir, J.; Ritchie, W. A. \& Wilmut, I. Sheep cloned by nuclear transfer from a cultured cell line. Nature, 380(6569):64-6, 1996.

Challah-Jacques, M. P. Chesne \& J. P. Renard. Production of cloned rabbits by somatic nuclear transfer. Cloning Stem Cells, 5:295-9, 2003.

Chesne, P.; Adenot, P. G.; Viglietta, C.; Baratte, M.; Boulanger, L. \& Renard, J. P. Cloned rabbits produced by nuclear transfer from adult somatic cells. Nat. Biotechnol., 20:3669, 2002.

Critser, J. K.; Riley, L. K. \& Prather, R. S. Application of nuclear transfer technology to wildlife species. In Reproductive Science and Integrated Conservation, pp 195-208. Eds WV Holt, AR Pickard, J Rodger \& De Wildt. Cambridge, Cambridge University Press, 2003.

Convention on the International Trade in Endangered Species of Wild Flora and Fauna). 2003. Appendix I, II, and III as adopted by the Conference of the Parties, valid from 16 October 2003. Available online at http://www.cites.org/ eng/append/latest_append.shtml

Da-Yuan Chen; Duan-Cheng Wen; Ya-Ping Zhang; Qing-Yuan Sun; Zhi-Ming Han; Zhong-Hua Liu; Peng Shi; Jin-Song Li; Jing-Gong Xiangyu; Li Lian; Zhao-Hui Koua; Yu-Qi
Wu; Yu-Cun Chen; Peng-Yan Wang \& He-Min Zhang. Interspecies Implantation and Mitochondria Fate of Panda-Rabbit Cloned Embryos. Biology of Reproduction, 67:637-42, 2002.

Diaz, N. I. \& Smith, Flueck, J. El huemul patagónico. L.O.L.A., Buenos Aires, 2000. 156 pp.

Drion, P. V.; Hanzen, C.; Wirth, D.; Beckers, J. F. \& Leboeuf, B. Physiologie de la reproduction et endocrinologie chez les cervidés: une revue. Ann. Med. Vet., 147:291-313, 2003.

Dung, V. V.; Giao, P. M.; Chinh, N. N.; Tuoc, D. \& MacKinnon, J. A new species of living bovid from Vietnam. Nature, 363:443-5, 1993.

Dung, V. V.; Giao, P. M.; Chinh, N. N.; Tuoc, D. \& MacKinnon, J. Discovery and conservation of the Vu Quang ox in Vietnam. Oryx, 28(1):16-21, 1994.

Frid, A. Into the last outpost of the huemul. Int. Wildlife, 21:149, 1991.

Frid, A. Observations on habitat use and social organization of a huemul Hippocamelus bisulcus coastal population in Chile. Biological Conservation, 67:13-9, 1994.

Frid, A. Huemul (Hippocamelus bisulcus) sociality at a periglacial site: sexual aggregation and habitat effects on group size. Canadian J. Zoology, 77:1083-1091, 1999.

Frid, A. Habitat use by endangered huemul (Hippocamelus bisulcus): cattle, snow, and the problem of multiple causes. Biological Conservation, 100:261-, 2001.

Galli, C.; Lagutina, I.; Crotti, G.; Colleoni, S.; Turini, P.; Ponderato, N.; Duchi, R. \& Lazzari, G. A cloned horse born to its dam twin. Nature, 424:635. 2003.

Giles, J.; Knight, J. Dolly's death leaves researchers woolly on clone ageing issue. Nature, 421:776, 2003.

Glade, A (ed). Libro rojo de los vertebrados terrestres de Chile. 2. ed. Santiago, Conaf, Impresiones comerciales. 1993. 65pp.

Heyman, Y.; Degrolard, J.; Adenot, P.; Chesne, P.; Flechon, B.; Renard, J. P. \& Flechon, J. E. Cellular evaluation of bovine nuclear transfer embryos developed in vitro. Reprod. Nutr. Dev., 35:713-23,1995. 
Holt, W.V.; Bennett, P. M.; Volobouev, V. \& Watson, P. F. Genetic resource banks in wildlife conservation. $J$. Zoology, 238:531-44, 1996.

Holt, W. V. \& Pickard, A. R. Role of reproductive technologies and genetic resource banks in animal conservation. Reviews in Reproduction, 4:43-150, 1999.

Holt, W. V.; Pickard, A. R.; Abaigar, T. \& Cano, M. Integrated approaches to the establishment of genetic resource banks for endangered gazelles. Proceedings of the 9th International Symposium on Spermatology, Cape Town. pp 127-132. Eds G Van der Horst, D Franken, R Bornman, T Bornman \& S Dyer. Bologna, Monduzzi Editore, 2002.

Holt, W; Pickard, A \& Prather, R. Wildlife conservation and reproductive cloning. Reproduction, 127:317-24, 2004.

International Union of Conservation of Nature and Natural Resources (IUCN) 2002 IUCN Red List of Threatened Species. http://www.redlist.org. Downloaded on 14 August 2002.

IUCN (International Union for Conservation of Nature and Natural Resources). 2004. 2004 IUCN Red List of Threatened Species. Available online at http:// www.redlist.org/

Jara, F. A.; Victoriano, P.; Maldonado, J.; Ortega, J.; Cosse, M.; González, S.; Sinclair, L. \& Crandall, K. Una aproximación a las relaciones de parentesco de Hippocamelus bisulcus (Cervidae, Artiodactyla) y otros ciervos neotropicales, basado en secuencias de citocromo b. www.salvemosalhuemul.c, 2003.

Jie, X. \& Xiangzhong, Y. Will cloned animals suffer premature aging - The story at the end of clones' chromosomes. Reproductive Biology and Endocrinology, 1:105, 2003.

Kemp, N.; Dilger, M.; Burgess, N. \& Van Dung, C. The saola Pseudoryx nghetinhensis in Vietnam - new information on distribution and habitat preferences, and conservation needs. Oryx, 31(1):37-44, 1997.

Lanza, F.; Cibelli, J.; Diaz, F.; Moraes, C.; Farin, P.; Farin, C; Hammer, C.; West, M \& Damiani, P. Cloning of an endangered species (Bos gaurus) using interspecies nuclear transfer. Cloning, 2:79-90, 2000a.

Lanza, R. P.; Cibelli, J. B.; Blackwell, C.; Cristofalo, V. J.;
Francis, M. K.; Baerlocher, G. M.; Mak, J.; Schertzer, M.; Chavez, E. A.; Sawyer, N.; Lansdorp, P. M. \& West M. D. Extension of cell life-span and telomere length in animals cloned from senescent somatic cells. Science, 288:665-9, 2000b.

Lincoln, G. A. \& Short, R. V. Seasonal breeding: nature's contraceptive. Recent Prog. Horm. Res., 36:1-52, 1980.

Locatelli, Y.; Mermillod, P. Caracteristiques et maitrise de la fonction de reproduction chez les cervidés. INRA Prod Anim., 18(1):23-5, 2005.

Onishi, A.; Iwamoto, M.; Akita, T.; Mikawa, S.; Takeda, K.; Awata, T.; Hanada, H. \& Perry, A. C. F. Pig cloning by microinjection of fetal fibroblast nuclei. Science, 289:1188-90, 2000.

Palma, G. Biotecnología de la Reproducción. Buenos Aires Aires. Ediciones Instituto Nacional de Tecnología Agropecuaria, 2001.

Polejaeva, A.; Chen, S. H.; Vaught, T. D.; Page, R. L.; Mullins, J.; Ball, S.; Dai, Y. F.; Boone, J.; Walker, S.; Ayares, D. L.; Colman, A. \& Campbell, K. H. S. Cloned pigs produced by nuclear transfer from adult somatic cells. Nature, 407:86-90, 2000.

Povilitis, A. The huemul in Chile: National symbol in jeopardy?. Oryx, 17:34. 1983a.

Povilitis, A. Social organization and mating strategy of the huemul (Hippocamelus bisulcus). J. Mammology, 64: 156-8, 1983b.

Povilitis, A. Social behavior of the huemul (Hippocamelus bisulcus) during the breeding season. Z. Tierpsy 68:26186, 1985.

Povilitis, A. Characteristics and conservation of a fragmented population of huemul (Hippocamelus bisulcus) in central Chile. Biological Conservation, 86:97-104, 1998.

Povilitis A. El estado actual del huemul (Hippocamelus bisulcus) en Chile central. Gayana, 66(1):59-68, 2002.

Prather, R. S.; Hawley, R. J.; Carter, D. B.; Lai, L. \& Greenstein, J. L. Transgenic swine for biomedicine and agriculture. Theriogenology, 59:115-23, 2003.

Rojas, M.; Venegas, F.; Servely, J. L. \& Guillomot, M. Clonación, producción de quimeras y células pluripotenciales. Int. J. Morphol., 22(4):343-50, 2004. 
Ryder, O. Cloning advances and challenges for conservation. Trends in Biotechnology, 20:231-2, 2002.

Ryder, O. \& Benirschke, K. The potential use of cloning in the conservation effort. Zool. Biology, 16(4): 295-300, 1997.

Saucedo, C. \& Gill, R. Huemul (Hippocamelus bisulcus) ecology research: conservation planning in Chilean patagonia. Deer specialist group, Newsletter, 19:13-5, 2004a.

Saucedo, C. \& Gill, R. The Endangered Huemul or South Andean deer Hippocamelus bisulcus. The International Journal of Conservation. Conservation News. Oryx, 38(2):132-3, 2004b.

Saucedo, C. \& Gill, R. La Ecología del Huemul del Sur. Revista Chile Forestal, 302:22-3, 2004c.

Saegusa, A. Mother bears could help save giant panda. Nature, 394:409, 1998.

Serret, A. El huemul: fantasma de la Patagonia. Buenos Aires, Zagur \& Urrutz Publications, 2001. 130 pp.

Shields, P. G.; Kind, A. J.; Campbell, K. H.; Waddington, D.; Wilmut, I.; Colman, A. \& Schnieke, A. E. Analysis of telomere lengths in cloned sheep. Nature, 399:316-7. 1999.

Shiga, K.; Fujita, T.; Hirose, K.; Sasae, Y. \& Nagai, T Production of calves by transfer of nuclei from cultured somatic cells obtained from Japanese black bulls. Theriogenology, 52(3): 527-535, 1999.

Shimozawa, N.; Ono, Y.; Kimoto, S.; Hioki, K.; Araki, Y.; Shinkai, Y.; Kono, T. \& Ito, M Abnormalities in cloned mice are not transmitted to the progeny. Genesis, 34: 203207. 2002.

Shin, T.; Kraemer, D.; Pryor, J.; Liu, L.; Rugila, J.; Howe, L.; Buck, S.; Murphy, K.; Lyons, L. \& Westhusin, M. A cat cloned by nuclear transplantation. Nature, 415(6874):859, 2002.

Spotorno, A. E.; Brum, N. \& Di Tomaso M. Comparative cytogenetics of South American deer. In Patterson BD \& RM Timm (Eds) Studies in neotropical mammalogy: essays in honor of Philip Hershkovitz. Fieldiana: Zoology, New Series 39. vii, 473-83, 1987. 506 pp.

Sutovsky, P.; Moreno, R. D.; Ramalho-Santos, J.; Dominko, T.; Simerly, C. \& Schatten G Ubiquitinated sperm mitochondria, selective proteolysis, and the regulation of mitochondrial inheritance in mammalian embryos. Biology of Reproduction, 63:582-90, 2000.

Wakayama, T.; Perry, A. C.; Zuccotti, M.; Johnson, K. R. \& Yanagimachi, R. Full-term development of mice from enucleated oocytes injected with cumulus cell nuclei. Nature, 394(6691):369-74,1998.

Wakayama, T.; Shinkai, Y.; Tamashiro, K. L.; Niida, H.; Blanchard, D. C.; Blanchard, R. J.; Ogura, A.; Tanemura, K.; Tachibana, M.; Perry, A. C.; Colgan, D. F.; Mombaerts, P. \& Yanagimachi, R: Cloning of mice to six generations. Nature, 407:318-9, 2000.

Wakayama, T. \& Yanagimachi, R. Mouse cloning with nucleus donor cells of different age and type. Molecular Reproduction and Development, 58:376-83, 2001.

Watson, P. F. \& Holt, W. V. Cryobanking the Genetic Resource. Wildlife Conservation for the Future? p 463. London and New York, Taylor \& Francis, 2001.

Wells, D. N. Cloning for animal conservation. Cloning, 2: 152-5, 2000.

Wells, D. N.; Misica, P. M.; Tervit, H. R. \& Vivanco, W. H. Adult somatic cell nuclear transfer is used to preserve the last surviving cow of the Enderby Island cattle breed. Reprod. Fertil. Dev., 10:369-78, 1998.

Wilmut, I.; Schnieke, A. E.; Mc Whir, J.; Kind, A. J. \& Campbell KHS. Viable offspring derived from fetal and adult mammalian cells. Nature, 385, 810-813. 1997.

Woods, G. L.; White, K. L.; Vanderwall, D. K.; Li, G. P.; Aston, K. I.; Bunch, T. D.; Meerdo, L. N. \& Pate, B. J. A Mule Cloned from Fetal Cells by Nuclear Transfer. Science, 301(5636):1063, 2003.

Dirección para correspondencia:

Prof. Dra. Mariana Rojas

Facultad de Medicina

Universidad de Chile

Santiago

Fono-Fax: 56-2-2225710

Email:mrojas@med.uchile.cl

Recibido : 19-05-2005

Aceptado: 09-08-2005 